\title{
Causes of the decline of the Gouldian Finch Erythrura gouldiae
}

\author{
SONIA C. TIDEMANN
}

\section{Summary}

Populations of Gouldian Finch Erythrura gouldiae, an estrildid endemic to northern Australia, declined markedly during the last two or three decades. A survey revealed the species in two areas of Northern Territory, with an estimated 2,00o individuals, including juveniles. Recaptures were low either because of mortality or dispersal. Gouldian Finches eat predominantly Sorghum spp. seeds, but consume other seeds before Sorghum ripens. Other finches declined as cattle increased. Gouldian Finches breed in tree hollows of predominantly two species of eucalypts that grow on rocky slopes. They require water within about $4 \mathrm{~km}$ of the nest site. There was no shortage of nesting hollows at the known breeding sites. Fires in the early to mid-dry season allow birds access to seed without damaging trees, but later fires can destroy trees with nest hollows and remove shade. Average clutch-size is 5.2. About $72 \%$ of eggs laid, and $63 \%$ of nests, fledged young. Pairs lay up to three clutches in a season (February-August), the length of which may depend on rainfall during the preceding wet season. Air-sac mite (Sternostoma tracheacolum), found in $62 \%$ of Gouldian Finches sampled, may be preventing the species recovering to former numbers. New colonies of Gouldian Finches should be identified, populations monitored, and habitat managed by effecting patchy burns by low-intensity fires early in the dry season.

\section{Introduction}

The Conservation Commission of the Northern Territory (CCNT) initiated research on the Gouldian Finch Erythrura gouldiae, an estrildine finch endemic to northern Australia, in 1986 following reports that their numbers in the wild had declined markedly. The species is known at least formerly to have ranged throughout northern Australia (north of $20^{\circ} \mathrm{S}$ ) from Cape Lévêque in Western Australia through Northern Territory into northern Queensland (Figure 1; see Blakers et al. 1984). Historical records, largely anecdotal, from early this century indicated that Gouldian, Long-tailed Poephila acuticauda and Masked P. personata Finches were abundant at waterholes across north-western Australia (e.g. Heumann 1926). Blakers et al. (1984) reported that both the range and numbers of the Gouldian Finch had declined, especially in populations to the south and east of the Gulf of Carpentaria (Figure 1). Returns from licensed finch trappers were collected annually by the Western Australian Department of Conservation and Land Management up to the end of 1986, when legal finch trapping was stopped: these returns show that from $1972 / 1973$ to 1981 there was a decline of $87 \%$ in the numbers of Gouldian Finches caught in Western Australia. As a 


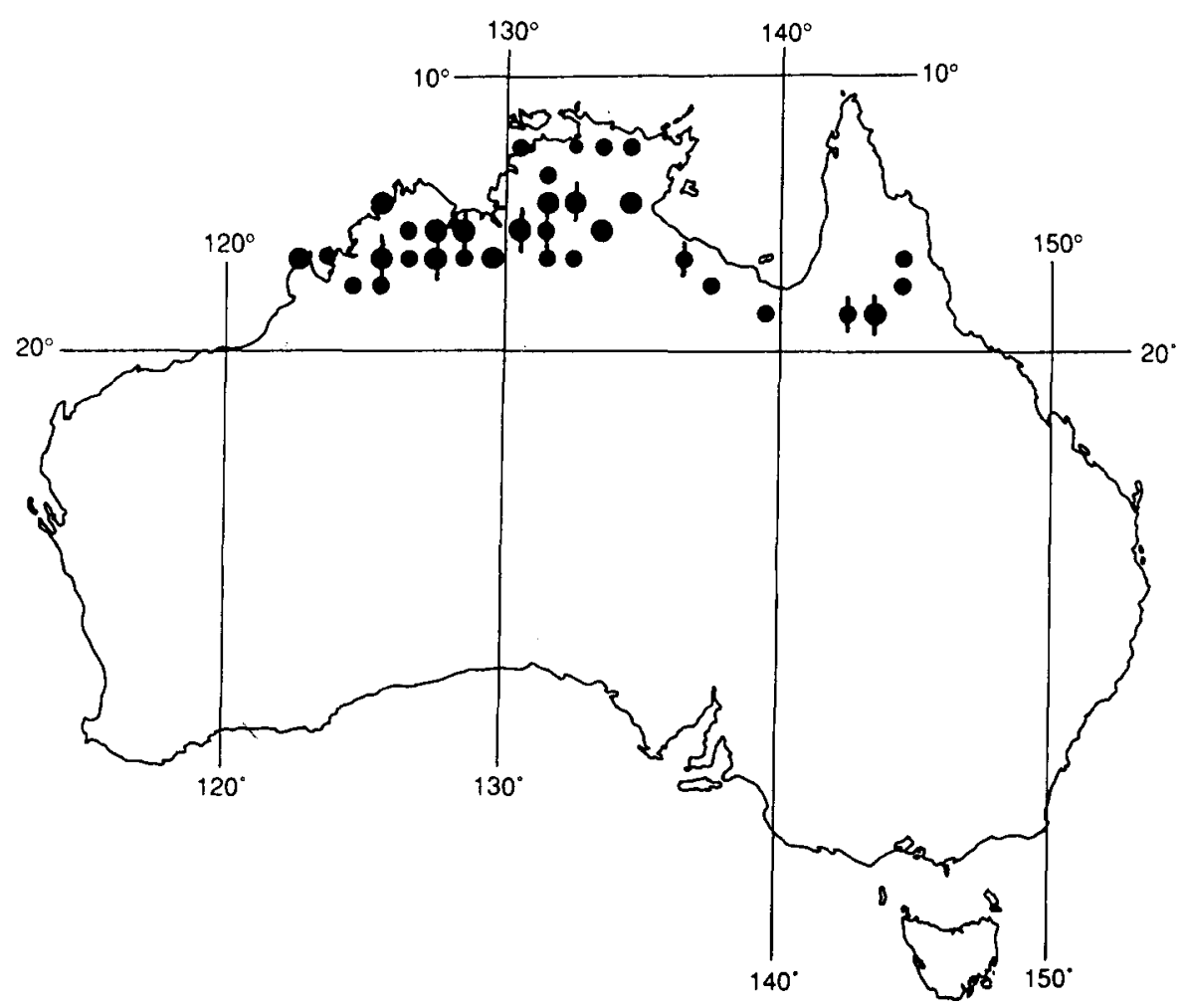

Figure 1. Distribution of the Gouldian Finch. Since 1950 there have been reports from only the central parts of its range. Sightings since 1985 are indicated by a vertical bar through the circle. (After Blakers et al. 1984.)

result none was trapped commercially after 1981. During the same period, the numbers of Long-tailed Finches caught increased.

The aim of the CCNT study was to determine what had caused the decline of the Gouldian Finch and to devise management plans to protect remaining populations. The first step was to obtain an indication of their abundance and distribution in the Northern Territory. During the late dry season (AugustDecember) 1986, finches were trapped, banded and released at 19 sites within the recorded Gouldian Finch range from central to western Northern Territory. Nine species were captured: Long-tailed Finch $(n=2,128)$, Masked Finch $(n=$ $1,122)$, Zebra Finch $P$. guttata $(n=879)$, Double-barred Finch $P$. bichenovii $(n=$ $566)$, Gouldian Finch $(n=22)$, Star Finch Neochmia ruficauda $(n=297)$, Pictorella Mannikin Heteromunia pectoralis $(n=133)$, Chestnut-breasted Mannikin Lonchura castaneothorax $(n=26)$, and Yellow-rumped Mannikin L. flaviprymna $(n=13$ ) (Table 1$)$. At these sites Gouldian Finches made up only $0.4 \%$ of captures. Captures were higher, however, at another site in the Northern Territory not included in the survey, Yinberrie Hills, where Gouldian Finches had been sighted for decades. There, 280 Gouldians were captured in the same period as above and these made up $34 \%$ of finches caught (Woinarski and Tidemann 1992). 
Table 1. Frequency of captures of finches in the Northern Territory (August-December 1986).

\begin{tabular}{lccc}
\hline Species & Number & $\%$ & Number of sites \\
\hline Long-tailed & 2,128 & 41 & 19 \\
Masked & 1,122 & 22 & 19 \\
Zebra & 879 & 17 & 13 \\
Double-barred & 566 & 11 & 13 \\
Star & 297 & 6 & 3 \\
Pictorella & 133 & 3 & 7 \\
Chestnut-breasted & 26 & 0.4 & 9 \\
Gouldian & 22 & 0.4 & 3 \\
Yellow-rumped & 13 & 0.3 & 3 \\
Total & 5,186 & & \\
\hline
\end{tabular}

Because most Gouldian Finches were found at Yinberrie Hills ( $14^{\circ} 08^{\prime} \mathrm{S}$ $\left.132^{\prime} 05^{\prime} \mathrm{E}\right)$ and on Newry Station $\left(16^{\circ} \mathrm{O} 8^{\prime} \mathrm{S} 129^{\circ} \mathrm{O} 5^{\prime} \mathrm{E}\right)$, these sites were selected for further intensive study. The climate is monsoonal, with the $80-90 \%$ of annual rainfall $(1,082 \mathrm{~mm}$ at Yinberrie, $873 \mathrm{~mm}$ at Newry) falling during the wet season, November to March.

\section{Population dynamics}

In the 1986 dry season banding study, finches were caught in mist-nets placed around water sources. Most netting was done in the first three to five hours of daylight. Birds caught were banded, weighed and the sex determined, if possible. Few were caught during the wet season because they were no longer concentrated around water sources.

From rates of recapture, the percentage of birds known to be alive in the months subsequent to banding decreased from Long-tailed to Masked to Gouldian Finches (Table 2). Few individuals were recaptured between years. Long-tailed and Masked Finches were known to be alive after 20-22 months whereas there were no records of Gouldian Finches 15 months after banding at Newry or after eight months at Yinberrie. The adult sex ratio of Gouldian Finches was biased, with a disproportionate number of males (1.5 males : 1 female) (Woinarski and Tidemann 1992).

Banded Gouldian Finches do not persist in the study areas owing to substantial mortality and/or dispersal. Data collected so far do not allow distinction between the two. Anecdotal reports (Berney 1903, Immelmann 1982) suggest that Gouldian Finches are nomadic; there are no suggestions for similar behaviour in Masked or Long-tailed Finches.

Table 2. Numbers of Gouldian, Long-tailed and Masked Finches banded and recaptured, Northern Territory, 1986-1990.

\begin{tabular}{lccc}
\hline & Banded & Recaptured & Recaptured (\%) \\
\hline Gouldian & 1,627 & 211 & 13 \\
Masked & 1,027 & 162 & 16 \\
Long-tailed & 2,802 & 608 & 22 \\
\hline
\end{tabular}


The populations of Gouldian Finches at Yinberrie and Newry are larger than any others found in the Northern Territory so far. Population estimates of Gouldian Finches at the two key sites suggest a total of about 2,000 birds $(1,500$ at Yinberrie and 500 at Newry). Because juveniles were included in the population estimates, the figures may be too high, but too few adults were recaptured to allow estimates of adults alone (Woinarski and Tidemann 1992). A search of trees at the study sites suggests that no more than 45 adult pairs nest on the study site at Newry and, possibly, 100 pairs at Yinberrie.

\section{Food eaten and food availability}

The food eaten by finches was determined by looking through the skin on the back of the neck and matching the contents of the crop against a reference collection obtained using Zann and Straw's (1984) method. The whole of the crop contents of road-killed or accidentally killed finches was examined. When feeding was observed, plant species were noted. Seed resource on the ground was measured by sweeping nine quadrats $\left(0.25 \times 0.75 \mathrm{~m}^{2}\right)$ within $2 \mathrm{~km}$ of each trapping site during the late dry season in 1986.

Gouldian Finches fed almost exclusively on seeds of native Sorghum spp., in particular S. stipoideum, S. plumosum, S. intrans and, to a lesser extent, S. australiense (Tidemann 1993b). During March-April, when Sorghum seeds are still attached to the plant, finches alight on the stalk and hop-flutter along it to the seed head to feed. Once the seed has dropped the birds feed on the ground in areas where the tall grass is sparse or has been burnt (Woinarski 1990, Tidemann et al. 1992c).

Rains falling early in the wet season cause seed to sprout. When this occurs finches appear to leave the area, moving to areas where food is available (pers. obs.). Later in the wet season the finches have been observed feeding on the grasses Xerochloa laniflora and Alloteropsis semialata, but as soon as the Sorghum matured the birds switched back to eating it. Other grass species eaten on a few occasions were Aristida dominii, Eriachne obtusa, Echinochloa colona, and three unidentified grass species. Gouldian Finches have never been observed feeding on insects and the only record $(n>900)$ of insect food taken was one ant that may have been picked up incidentally. Gouldian Finches feed their nestlings exclusively on Sorghum at three of four sites studied and predominantly on Sorghum at the fourth. Juveniles have been observed feeding on Sehima nervosum as well as Sorghum.

There is no shortage of Sorghum within the distributional range of the Gouldian Finch. It varied from about a quarter of the vegetation biomass present in the dry season trapping sites to up to three-quarters in the known breeding areas. The seeds of grass species most commonly found in ground sweepings correlated with those eaten by finches in the area. Gouldian Finches were found at sites with high amounts of Sorghum (Tidemann 1990).

\section{Effects of the pastoral industry}

Information on the number of cattle run on utilizable land, numbers of feral horses and donkeys, and percentage of the area of the pastoral property burnt 
annually was obtained from the managers of eight properties where trapping had been carried out (Tidemann 1990).

Although the total numbers of finches caught declined as the number of cattle increased, too few Gouldian Finches were caught to be analysed separately. As cattle numbers increased so did the amount of bare ground especially around watering points. Neither the amount of land burnt annually nor the number of feral animals in the area affected the number of finches caught.

Sorgum stipoideum grows on rocky slopes that are not usually utilized by cattle and it is unlikely that cattle would cause a shortage of food. The larger number of watering points now provided for cattle may have benefited finches (Knight 1989).

Long-tailed and Masked Finches were caught at all sites, Zebra Finches and Pictorella Mannikins in more open savanna, and Double-barred and Star Finches at sites with intermediate characteristics (Figure 2). Gouldian Finches, however, occurred patchily across the gradient and so could not be related to a particular vegetation structure in terms of their habitat use during the dry season.

Gouldian Finches nest in hollows that have been formed by termites. The favoured termite-prone tree species are Eucalyptus tintinnans (at Yinberrie) and E. brevifolia (at Newry). The two breeding areas differed floristically, particularly in terms of the eucalypts present. Within each area, however, the floristics of the breeding and feeding sites did not differ, nor did they differ from sites chosen at random (Tidemann et al. 1992c). The characteristics of breeding sites selected by Gouldian Finches and common to both localities are that they are rocky with trees larger and closer together than random sites.

Within the range of the Gouldian Finch, the requirements of the non-breeding season sites appear to be the presence of Sorghum and water within $10 \mathrm{~km}$, while the breeding sites require Sorghum, water within $4 \mathrm{~km}$ and hollow $E$. tintinnans or E. brevifolia trees.

\section{Fire}

It has been suggested that widespread burning of annual grasses may have led to the decline in numbers of the Gouldian Finch (Blakers et al. 1984).

Woinarski (1990) reported an increase in the numbers of granivorous birds, including the Gouldian Finch, in areas following fires during April, June and August. Fires, at least in the early to mid-dry season, increase the accessibility of food to granivores by clearing away the grass layer. Sorghum spp. can grow from $1.5-2.5 \mathrm{~m}$ in height and form a thick cover when they die off and collapse.

The scorch height of Woinarski's August fire was double that of April and the probability that fires later again could have an even higher intensity and cause trees to lose their leaves completely is real (pers. obs.). This means that there is no shelter for birds and, coupled with the total removal of the grass layer, there are large amounts of radiant heat from both above and below in burnt areas (Tidemann 1993a). Biannual counts at waterholes in the east Kimberleys (north Western Australia) indicated that finches cease to frequent 


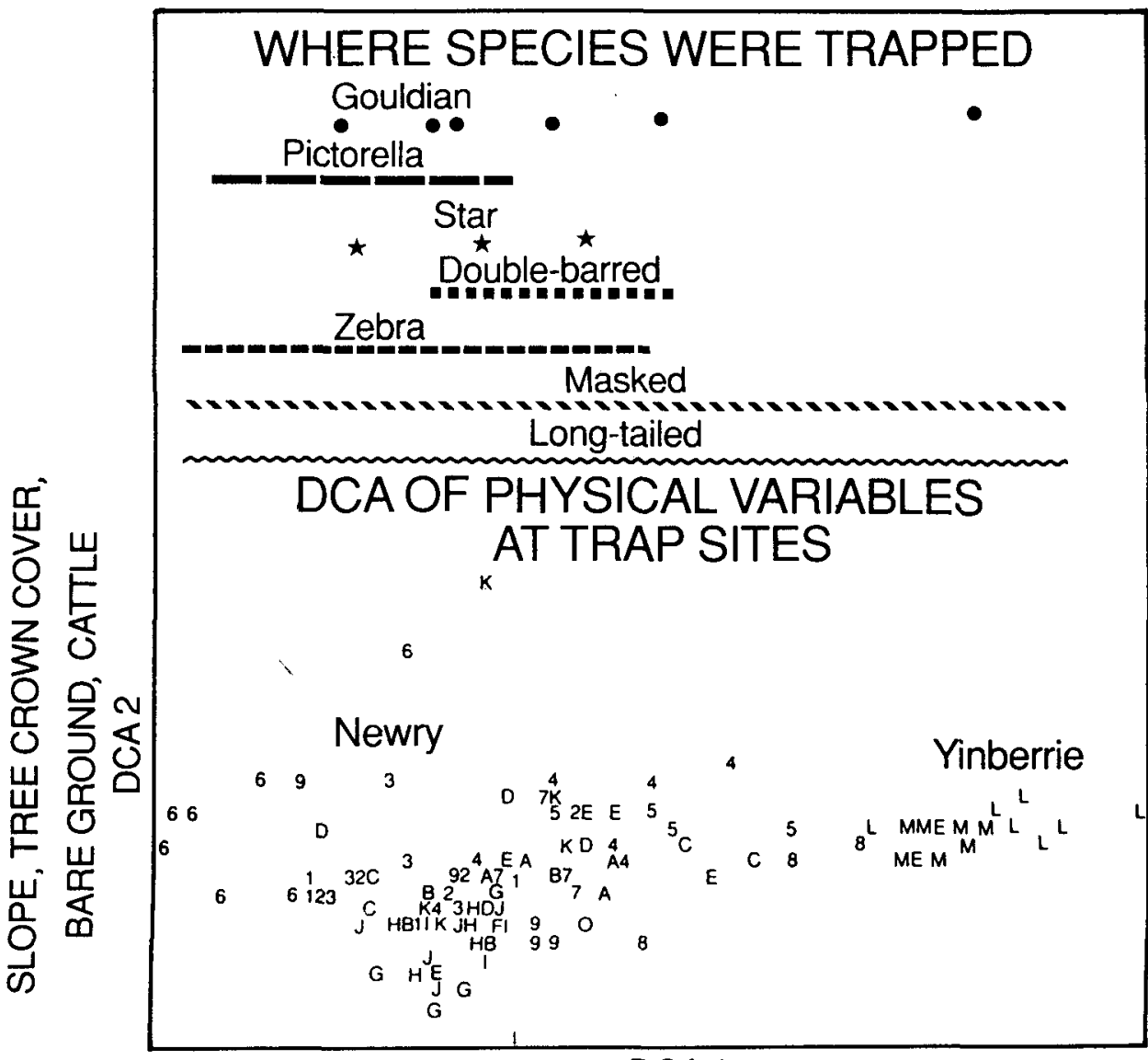

\section{DCA 1}

TREE \& BUSH HEIGHTS, SOIL TEXTURE

Figure 2. The lower part of the figure shows a scattergram from Detrended Correspondence Analysis (DCA) of seven environmental variables (slope, aspect, soil type \& $\mathrm{pH}$, vegetation characteristics, etc.) at 22 sites $(1-9, A-M)$ where finches were trapped, banded and released, August-November, 1986. X-axis, DCA 1, increasing tree and bush heights and soil coarseness; Y-axis, DCA 2, decreasing slope, tree crown cover, bare ground and cattle; $\mathrm{L}, \mathrm{M}=$ Yinberrie; $1,2,3=$ Newry. The upper part of the figure shows the locations at which each species of finch was caught in relation to DCA 1: Long-tailed and Masked Finches were caught at all locations, Gouldian at only six.

usual, permanent water sources if the surrounds have been exposed to intense, late dry season fires (pers. obs.).

Although Sorghum intrans germinates best in unburnt communities (Mott and Andrew 1985), the density of viable seeds is reduced by only about $38 \%$ following early dry season fires (Andrew and Mott 1983). In contrast, a fire during the wet season, following the emergence of Sorghum seedlings, can eliminate populations completely because Sorghum lacks a persistent seed bank (Watkinson et al. 1989). A compromise needs to be reached whereby fuel load is reduced to prevent the high-intensity fires of the late dry season but minimal 
damage is done to the seed bank. This would best be achieved by burning the grass layer as soon as the seed has dropped from the stalks.

Gouldian Finches are almost entirely dependent on hollows in trees for nest sites (Schodde and Tidemann 1986). Fire can burn the insides of the tree hollows if it funnels up through openings at the bottom. No nests have been found in hollows which are blackened on the inside. Mature eucalypts destroyed by fire respond by sending up new shoots from an underground lignotuber. Thus although trees are not killed, the availability of hollows is affected. It is not known how long it takes for a eucalypt to grow to the size where hollows, when formed, are of suitable dimensions for breeding sites. If a patch of trees is burnt regularly by hot fires, potential breeding sites may disappear completely and seedling stock may never mature.

\section{Breeding biology and nest-site selection}

Gouldian Finches are the only Australian finches to nest exclusively in hollows, usually in trees although there are historical reports of them nesting in termite mounds. Nests have been found in only two species of tree (see above). Long-tailed Finches also nest in hollows but frequently build nests in the foliage of trees.

A study was conducted to determine the availability of nest sites at the known breeding sites (Yinberrie and Newry). Measurements were made of the tree and the hollow (its orientation in the tree, bearing of opening, height, diameter of entrance and its inclination) for Gouldian and Long-tailed Finch nest sites, as well as random hollows. Gouldian Finches selected hollows of smaller internal diameter than Long-tailed Finches, nested deeper into the hollow (Figure 3) and on steeper slopes. Both finches selected hollows that were inclined upwards, higher, and in trees with fewer trunks and larger cross-sectional area (at breast height) than randomly available (Table 3) (Tidemann et al. 1992C). Nest entrances were oriented north-westerly as were the random entrances at Newry, but at Yinberrie Gouldian Finches avoided openings oriented towards the south (Figure 4). Discriminant analyses indicated that about one-fifth of the random hollows and a third of Long-tailed nest sites were classified as Gouldian (Tidemann et al. 1992c) and yet remained empty. Hence there was no shortage of apparently suitable hollows at the known breeding sites.

Social factors may also be important in the selection of nest sites, and the spacing between nests was measured. There is low apparent survival between years, so it is not known whether birds return to the same hollow. Some hollows are used more frequently than can be attributed by chance, so either there are social factors operating or birds are assessing hollows differently from us. Thus, there may be fewer hollows available than those indicated from the discriminant analyses, with the added potential of competition between species for hollows. The decision was made not to interfere with the natural situation, e.g. by providing artificial nest-boxes, until further data have been collected.

Clutch-size of the Gouldian Finch is $5.2 \pm 1.3(n=60)$ (Tidemann et al. in press). About three-quarters $(72 \%)$ of the eggs $(n=232)$ hatched and $81 \%$ of nestlings $(n=166)$ fledged (Table 4$)$. Nearly two-thirds $(63 \%)$ of nests $(n=48)$ were successful in fledging young, $22 \%$ were presumed to have been preyed 

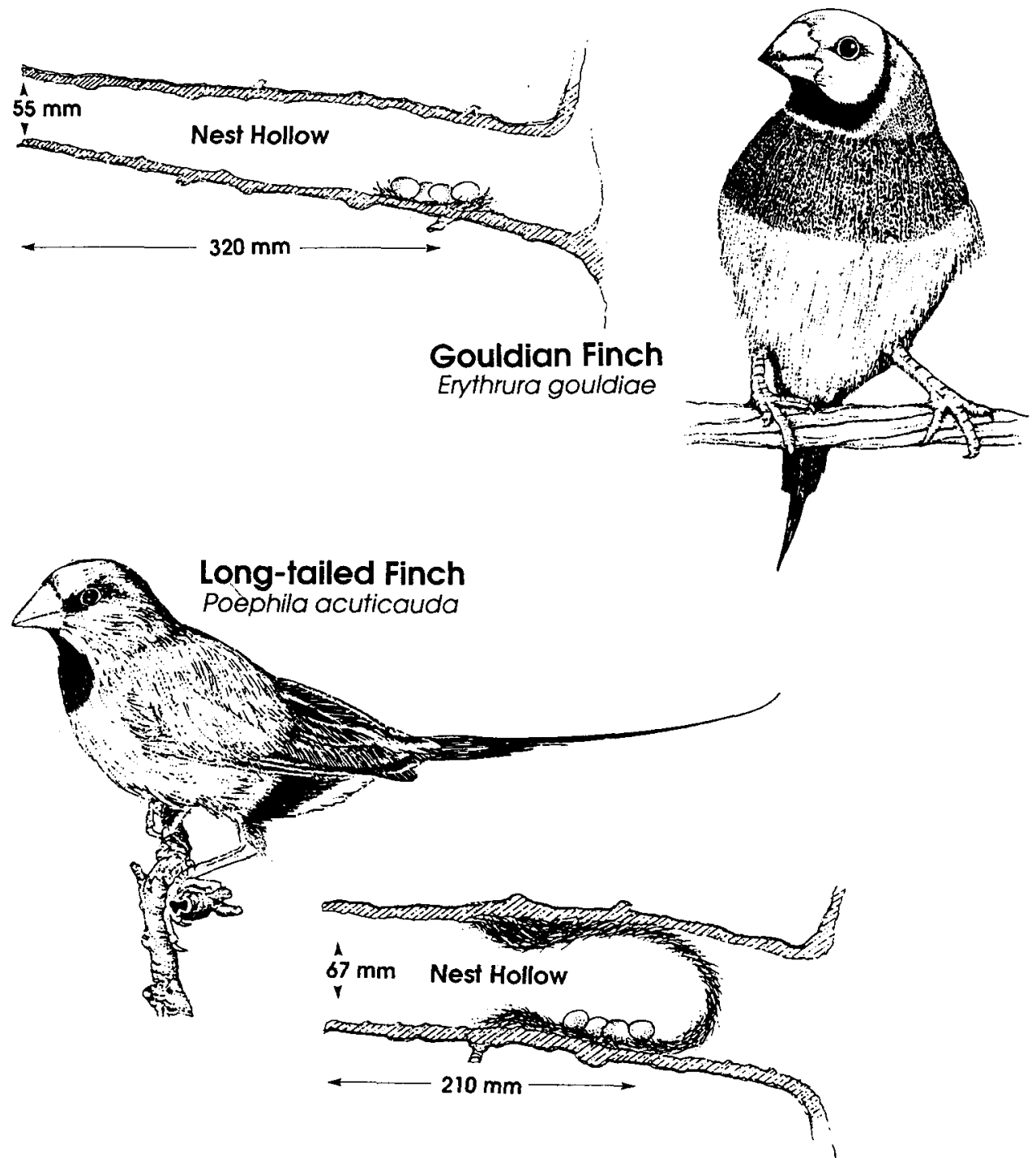

Figure 3. Characteristics of the hollows selected as breeding sites by Gouldian and Longtailed Finches.

Table 3. Characteristics (means) of variables measured at nest sites of Gouldian and Long-tailed Finches and trees chosen randomly.

\begin{tabular}{lccc}
\hline & \multicolumn{3}{c}{ Nest sites } \\
\cline { 2 - 4 } & Gouldian & Long-tailed & Random \\
\hline Tree Height $(\mathrm{m})$ & 9.6 & 9.7 & 9.4 \\
Nest Height $(\mathrm{m})$ & $3 \cdot 7^{a}$ & $3.5^{a}$ & 2.9 \\
Number of trunks per tree & $1.7^{a}$ & $1.8^{a}$ & 2.3 \\
Diameter of trunk bearing nest $(\mathrm{m})$ & $0.3^{a}$ & $0.32^{a}$ & 0.29 \\
Depth of hollow $(\mathrm{m})$ & 0.47 & 0.62 & 0.52 \\
\hline
\end{tabular}

${ }^{a}$ Significantly different from random. 
Newry

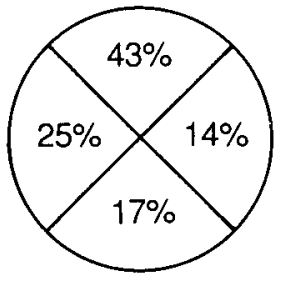

Gouldian

$n=83$

Yinberrie

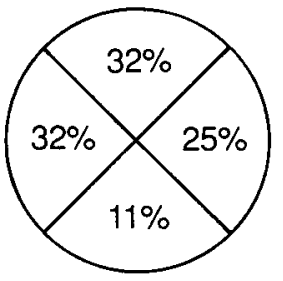

Gouldian

$n=63$

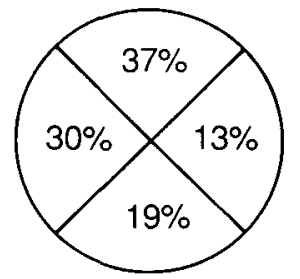

Long-tailed

$n=165$

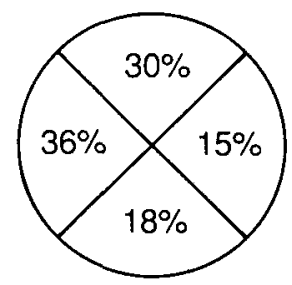

Long-tailed

$n=33$

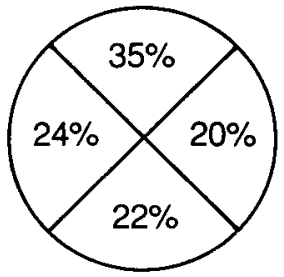

Random

$\mathrm{n}=55$

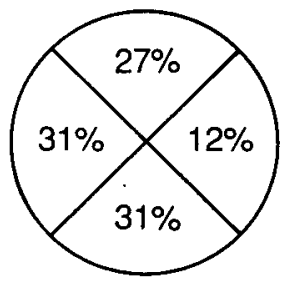

Random

$\mathrm{n}=59$

Figure 4. Bearing of the entrance of hollows selected by Gouldian and Long-tailed Finches as breeding sites, and hollows chosen at random.

Table 4. Clutch and brood sizes and success of Gouldian Finches 1989-1991, Northern Territory.

\begin{tabular}{lc}
\hline Gouldian Finch & Breeding output $1989-1991$ \\
\hline Average clutch size $(n=60)$ & 5.2 \\
$\%$ young hatched $(n=232)$ & 72 \\
$\%$ young fledged $(n=134)$ & \\
of eggs laid & 58 \\
of young hatched & 81 \\
\% nests successful & 63 \\
preyed on & 22 \\
abandoned & 16 \\
\hline
\end{tabular}

upon, and $16 \%$ were abandoned. The small Goanna Varanus timorensis has been observed preying on nestlings (Tidemann et al. 1992d). Another likely predator is the brown tree snake Boiga irregularis, which has been found in tree hollows. There was an inverse relationship between the number of young that fledged and the diameter of the hollow entrance $(r=-0.247, P<0.1, n=50)$. No other aspect of the nest sites was correlated with nesting success. There were no differences between breeding output at Newry for 1989 and 1991 and data were pooled. Insufficient data were obtained at Yinberrie to make yearly comparisons. 
Table 5. Proportions of white and red blood cells and weights of finches and mannikins, Northern Territory, August-December, 1986.

\begin{tabular}{lccr}
\hline & Total white cells : 1, ooo red cells & $\begin{array}{c}\text { Mature } \\
\text { red cells }(\%)\end{array}$ & \multicolumn{2}{c}{$\begin{array}{c}\text { Weight } \\
(\mathrm{g})\end{array}$} \\
\hline Double-barred & 7.42 & 70 & 8.3 \\
Pictorella & 4.35 & 63 & 14.1 \\
Long-tailed & 7.12 & 76 & 13.4 \\
Masked & 6.69 & 69 & 12.4 \\
Star & 6.45 & 67 & 10.4 \\
Zebra & 5.29 & 62 & 10.9 \\
Chestnut-breasted & 5.43 & 73 & 13.3 \\
Gouldian & 7.04 & 72 & 13.7 \\
\hline
\end{tabular}

Average clutch-size remained constant between years even though the breeding season in 1990 was shorter (four months) than in 1989 (six months). Pairs may have up to three successful clutches in a season. The length of the breeding season may be related to the amount of rainfall in the preceding wet season. Data collected so far suggest that some factor other than breeding output is preventing the recovery of population numbers.

\section{Parasites and disease}

Indications of the presence of viral or bacterial diseases were ascertained by examining blood smears made during the mist-netting survey carried out in 1986 (see above). Blood smears were stained (with Giemsa), examined under oil immersion, and the proportions of white cells counted (Tidemann et al. 1992a). The numbers of white cells (total) varied by only $41 \%$ between the eight species (Table 5), with Gouldian Finches falling within the range of the others. Smears were also examined for the presence of malarial parasites, microfiliariae and trypanosomes, but none was found. The proportions of mature, intermediate and immature red blood cells were estimated. Mature cells made up about two-thirds of the total erythrocyte count with immatures $5 \%$ or less (Table 5). From these results it appeared that none of the finch species was diseased by factors causing a haematological response. This does not preclude, however, the possibility of earlier infections or of infestation by parasites that prompt an immunological reaction elsewhere in the body or that were situated in immunologically privileged sites.

Aviculturists who keep Gouldian Finches have reported the presence of air-sac mite Sternostoma tracheacolum which, if left unchecked, leads to severe wheezing, reduced activity and fecundity, and even death. There is no indication from aviculturists that any individuals have developed a resistance to infection by air-sac mites. Although this parasite had never been reported in wild birds, it was possible that, if present, it was affecting the Gouldian Finch and maybe other species.

A survey of finches from northern Western Australia, the Northern Territory and Queensland revealed that $62 \%$ of the Gouldian Finches were infested with air-sac mite (Tidemann et al. 1992b, 1993). It was also found in one Masked 
Finch (0.01\% of 118 birds dissected) and one Pictorella Mannikin (of eight dissected). None of the other five species of finch or mannikin $(n=260)$, all of which are common and co-occur with Gouldian Finches, was infested with air-sac mite. A further 240 individuals (road kills, museum specimens, from mist-nets) of 58 other genera were examined for air-sac mite but it was present in none. In the affected Gouldian Finches it was found throughout the respiratory system and sometimes in the body cavity (Tidemann et al. 1992b). Many individuals had partially occluded tracheas because of the presence of mites and their mucous covering.

Of 12 Gouldian Finches examined histologically, four had mites evident in the respiratory system. Three of these birds had the pathology of birds with broncho-pneumonia, thickened air-sac linings and some consolidation of the lungs. Sternostoma tracheacolum may be having an effect on the viability of infested birds in the wild. Affected individuals may be less capable of the nomadic behaviour suggested for the Gouldian Finch. This parasite, even if it did not cause the massive decline of the Gouldian Finch, may be suppressing a return to its former status.

In a preliminary study of wild-caught birds, it was found that a $20 \mu$ l dose of Ivomec (a water-soluble, broad-spectrum, sheep anthelminthic) killed air-sac mite. Control, untreated birds had live mites moving around within the air-sacs. Smaller but recommended doses of Ivomec (Madill 1987) were found to be ineffective. Results from preliminary treatment of birds in the wild with oral doses of Ivomec are inconclusive because recaptures of Gouldian Finches are rare. Work is continuing on the dynamics of the mite and the best dose for effective treatment.

\section{A strategy for management}

Neither food availability during the dry season nor breeding success appears to be limiting Gouldian Finch populations. It is not possible to determine whether the species was subjected to bacterial or viral disease in the past but there is no evidence of them suffering from such effects in the present. Surveys of hollows at presently known breeding sites suggests that there are hollows that are not being utilized by Gouldian Finches.

The main factor that appears to be keeping populations of Gouldian Finches suppressed, even if it was not the cause of their decline in the 1970s, is the occurrence of air-sac mite. When a fully effective, non-toxic dose has been determined it is planned to dose birds orally and ascertain whether treated birds are recaptured more, and over longer periods, than untreated birds. Transmission of air-sac mite is thought to be direct from parent to nestling, probably during feeding. The air-sac mites found in the trachea are mostly gravid females (P. Bell pers. comm.). Theoretically, we should be able to build up the numbers of Gouldian Finches that are free of air-sac mite. If this is the case, larger-scale treatment could be carried out by treating the water in the artificial suppliers at the study sites where the progress of Gouldian Finches is monitored.

Gouldian Finches breed well in captivity and release programmes have been suggested. This should not be done without matching the genotypes of the 
birds currently held in aviaries with those in the wild, if that is possible. Matching genotypes is an expensive procedure. Even if this was done, it would be better not to release captive-bred birds into the wild before the factor that is keeping the population low is identified. There is also the chance that diseases could be accidentally introduced into the wild. It is still unclear how the air-sac mite became established in the wild Gouldian Finch population.

In many cases where terrestrial vertebrate species have declined markedly in numbers, the reason has been the destruction of either feeding or breeding habitat. This does not appear to be the case with the Gouldian Finch. It is essential, however, to protect patches of habitat that satisfy the requirements for breeding, especially if the species continues to occupy these areas after the breeding season. The high annual mortality of birds suggests that, like other species, the period from when they leave known areas until the onset of breeding the following year is critical for survival and warrants investigation (Tidemann 1993a). If individuals that are approaching their first breeding season come, during their reported nomadic wanderings, to habitat that is suitable for breeding, it is possible that new breeding colonies could become established.

In spite of extensive searches in a variety of places, all of which appear to possess suitable breeding sites, we know of only a few substantial breeding colonies in the Northern Territory. It is essential to protect these as well as to identify others. The plan for the future is to model the habitat data collected to assist with predicting where Gouldian Finches might occur and investigate these areas. Substantial populations should be incorporated into reserves where possible. Habitat should be managed to minimize high-intensity fires not only to protect the suitable trees but also to ensure that there is shade available at the end of the dry season. These aspects of Gouldian Finch conservation must continue until strongholds and sizeable populations are identified that will ensure the future of the species.

\section{Acknowledgements}

I would like to thank all who have contributed to this project both as employees and volunteers, in particular J. Woinarski, R. Elvish, J. Elvish, J. Boyden, B. O'Gorman, B. Wilson, I. Morris, B. Grey, C. Burgoyne, E. Strauss, P. Bell, C. Allen, A. Smith, C. Palmer, N. Dreyer, T. Hunt, C. Lawson, O. Price and staff of the Territory Wildlife Park; to W. J. Freeland and P. J. Whitehead for guiding support; and to the World Wide Fund for Nature (Australia) for financial support.

\section{References}

Andrew, M. H. and Mott, J. J. (1983) Annuals with transient seed banks: the population biology of indigenous Sorghum species of tropical north-west Australia. Aust. J. Ecol. 8: $265-276$.

Berney, F. L. (1903) North Queensland notes on some migratory birds. Emu 2: 2-10. 
Blakers, M., Davies, S. J. J. F. and Reilly, P. N. (1984) Atlas of Australian birds. Melbourne: Melbourne University Press.

Heumann, G. A. (1926) Birds in the Northern Territory and the new finch. Emu 25: 134136.

Immelmann, K. (1982) Australian finches. Sydney: Angus and Robertson.

Knight, M. H. (1989) Importance of borehole water to doves and sandgrouse in the semi-arid southern Kalahari. S. Afr. J. Wildl. Res. 19: 42-46.

Madill, D. (1987) Parasitic diseases. Pp.45-59 in P. Macwhirter, ed. Everybird: a guide to health. Sydney: Inkata.

Mott, J. J. and Andrew, M. H. (1985) The effect of fire on the population dynamics of native grasses in tropical savannas of north-west Australia. Proc. Ecol. Soc. Aust. 13: 231-239.

Schodde, R. and Tidemann, S. C., eds. (1986) Complete book of Australian birds. Sydney: Reader's Digest.

Tidemann, S. C. (1990) The relationship between finches and pastoral practices in northern Australia. Pp.305-315 in J. Pinowski and J. D. Summers-Smith, eds. Granivorous birds and agriculture. Warsaw: PWPN-Polish Scientific Publishers.

Tidemann, S. C. (1993a) Where are the Gouldian Finches after the breeding season? Victorian Nat. 110: 238-243.

Tidemann, S. C. (1993b) Management of a threatened species - the Gouldian Finch example. Pp.123-131 in C. P. Catteral, P. V. Driscoll, K. Hulsman, D. Muir and A. Taplin, eds. Birds and their habitats: status and conservation in Queensland. Brisbane: Queensland Ornithological Society.

Tidemann, S. C., Calley, M. and Burgoyne, C. (1992a) An investigation of blood smears of northern Australian finches. Emu 92: 114-117.

Tidemann, S. C., McOrist, S., Woinarski, J. C. Z. and Freeland, W. J. (1992b) Heavy parasitism of wild Gouldian Finches Erythrura gouldiae by the air-sac mite Sternostoma tracheacolum. J. Wildl. Diseases 28: 80-84.

Tidemann, S. C., Boyden, J., Elvish, R., Elvish, J. and O'Gorman, B. (1992c) Comparison of the breeding sites and habitat of two hole-nesting estrildid finches, one endangered, in northern Australia. J. Trop. Ecol. 8: 373-388.

Tidemann, S. C., Palmer, C., Boyden, J. and Hunt, T. (1992d) Predation on the Gouldian Finch Erythrura gouldiae by reptiles. Corella 16: 105-106.

Tidemann, S. C., McCartney, J. and Smith, I. (1993) The Gouldian Finch and air-sac mite in Queensland. Sunbird 23: 36-40.

Tidemann, S. C., Lawson, C., Elvish, R., Boyden, J. and Elvish, J. (in press) Breeding biology of the Gouldian Finch (Ploceidae: Erythrura gouldiae), an endangered finch of northern Australia. Emu.

Watkinson, A. R., Lonsdale, W. M. and Andrew, M. H. (1989) Modelling the population dynamics of an annual plant Sorghum intrans in the wet-dry tropics. J. Ecol. 77: 162-181.

Woinarski, J. C. Z. (1990) Effects of fire on the bird communities of tropical woodlands and open forests in northern Australia. Austral. J. Ecol. 15: 1-22.

Woinarski, J. C. Z. and Tidemann, S. C. (1992) Survivorship and some population parameters for the endangered Gouldian Finch Erythrura gouldiae and two other finch species at two sites in tropical northern Australia. Emu 92: 33-38.

Zann, R. and Straw, B. (1984) A non-destructive method to determine the diet of seed-eating birds. Emu 84: 40-41.

SONIA C. TIDEMANN

Conservation Commission of the Northern Territory, P.O. Box 496, Palmerston, NT o831, Australia 